\title{
Mass wasting processes - offshore Sumatra
}

\author{
D. R. Tappin
}

British Geological Survey, Nottingham, England

L. C. McNeil, T. Henstock

National Oceanography Centre, Southampton, England

D. Mosher

Bedford Institute of Oceanography, Natural Resources Canada, Challenger Dr., Dartmouth,, NS B2Y 4A Canada

\begin{abstract}
Earthquakes are a commonly cited mechanism for triggering submarine landslides that have the potential to generate locally damaging tsunamis. With measured runups of over 35 metres in northern Sumatra from the December $26^{\text {th }} 2004$ tsunami source, these runups might be expected to be due, in part, to local submarine landslides. Mapping of the convergent margin offshore of Sumatra using swath bathymetry, single channel seismic and seabed photography reveals that seabed failures are common, but mainly small-scale, and composed of blocky debris avalanches and sediment flows. These failures would have contributed little to local tsunami runups. Large landslides are usually formed where there is significant sediment input. In the instance of Sumatra, most sediment is derived from the oceanic plate, and there is little sediment entering the system from the adjacent land areas. Input from the oceanic source is limited because of the diversion of sediment entering the subduction system off of Sumatra, that is attributed to collision between the Ninetyeast ridge and the Sunda Trench at approximately 1.5 million years ago.
\end{abstract}

Keywords: Sumatra margin, tsunami, mass wasting, multibeam bathymetry, single channel seismic.

\section{Introduction}

The December $26^{\text {th }} 2004$ earthquake in the Indian Ocean was the worlds largest for over 40 years and created the most devastating tsunami ever recorded, with fatalities around the Indian Ocean of over 220,000. The Sumatran subductionzone system is subject to great (Mw 8-9) earthquakes, (e.g., Newcomb and McCann, 1987; Ortiz and Bilham, 2003). Earthquakes are a commonly cited mechanism for triggering submarine landslides (e.g. Hampton et al., 1996; Lee et al., 2007). However, it has only recently been recognized that they can generate 
locally damaging tsunamis (e.g. Papua New Guinea 1998, Seward 1964, Grand Banks 1929, and Storegga 8,200BP). Thus runups of over 35 metres reported from Banda Aceh in northern Sumatra, close to the tsunami source, might have been enhanced by the failure of local submarine landslides. In 2004, knowledge of offshore bathymetry for the region off Sumatra was generally poor because of the sparse coverage of single-beam echo soundings. However, in the Aceh Basin there was some evidence for sediment failures identified from arcuate features on GEBCO bathymetric maps. In 1998 a submarine slump located in an arcuate shaped feature off of northern Papua New Guinea caused a tsunami that led to over 2,000 deaths (Tappin et al, 2001). In January 2005 multibeam bathymetry was acquired offshore of northern Sumatra (Figure 1) (Henstock et al, 2006). This was the first seafloor survey immediately after a great subduction-zone earthquake; and an ideal opportunity to identify coseismic deformation features in soft sediment. During a second marine survey in August, 2005 additional single channel seismic (SCS) data were acquired in the same region (Moran and Tappin, 2006). Based on these datasets, we here report on the active mass wasting processes taking place in the mapped region and their regional controls. We describe the seabed morphology based on the multibeam data and the related subseabed structure interpreted from the SCS. By this means we determine the 3D architecture of the primary mechanisms through which mass wasting is taking place in the region.

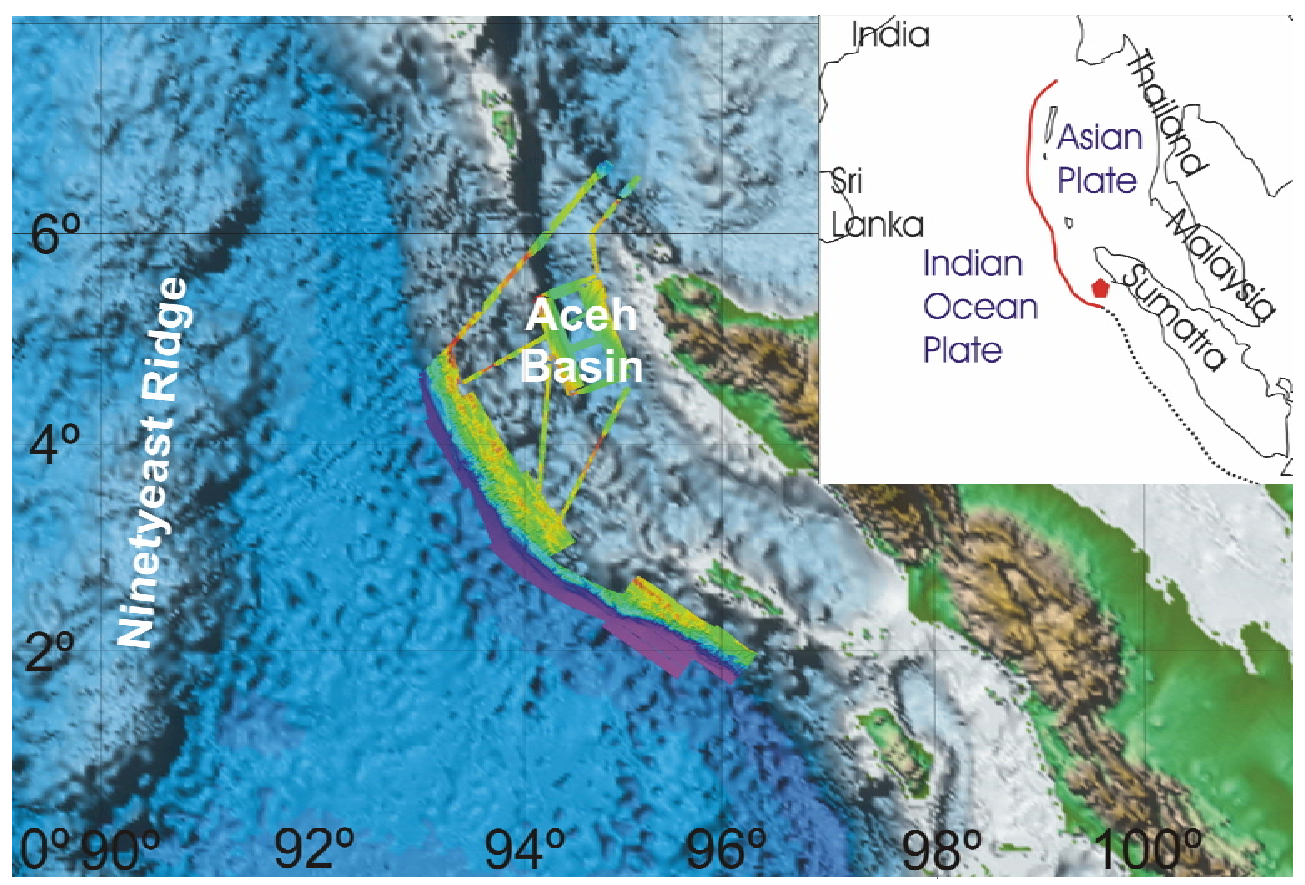

Figure 1. Map of the margin off Sumatra and the location of the HMS Scott bathymetry data. Inset shows of the December $26^{\text {th }}$ rupture (in red) and the earthquake epicentre (red hexagon). The bathymetry is underlain by satellite altimetry (Smith and Sandwell, 1997).

\section{Methodology}

The swath bathymetric data were acquired by the Royal Navy hydrographic vessel 
HMS Scott, in January- February 2005, using a $12 \mathrm{kHz}$ SASS-IV system with 361 beams and a $120^{\circ}$ swath width. The theoretical beam width (horizontal resolution) is $\sim 25 \mathrm{~m}$ directly beneath the ship to $100 \mathrm{~m}$ for the outer beams (50-60 ${ }^{\circ}$ ) (flat seabed, $4500 \mathrm{~m}$ depth). The ideal depth precision (vertical resolution) is $\sim 5 \mathrm{~m}$ directly beneath the ship, assuming no position or attitude errors and using Rayleigh's criterion; smaller features might be identifiable due to their coherence over several pings. Minor roll artifacts and noise may reduce the vertical precision to $10-15 \mathrm{~m}$ for outer beams. Bathy-thermographs (XBTs) were taken at $<3 \mathrm{~h}$ intervals to constrain water sound velocity. Available pre-existing bathymetry data in the area are sparse, single beam, and subject to navigation errors. The seismic data and seabed images were acquired aboard the RV Performer in August 2005. The seismic reflection profiling system consisted of a pneumatic sound source, a Seismic Systems Inc. Generator Injector (GI) gun (or a two GI gun array) and a hydrophone, the Teledyne model 28420 streamer, $61 \mathrm{~m}$ (200 ft) in length.

\section{Seabed morphology and structure}

The two main areas mapped were the Aceh Forearc Basin, lying offshore of northern Sumatra and a $\sim 550 \mathrm{~km}$ long section of the central Sunda convergent margin, including the outer-arc high fault system (Figures 1 and 2). It is in the southern part of this region that the December 2004 earthquake epicenter is located.

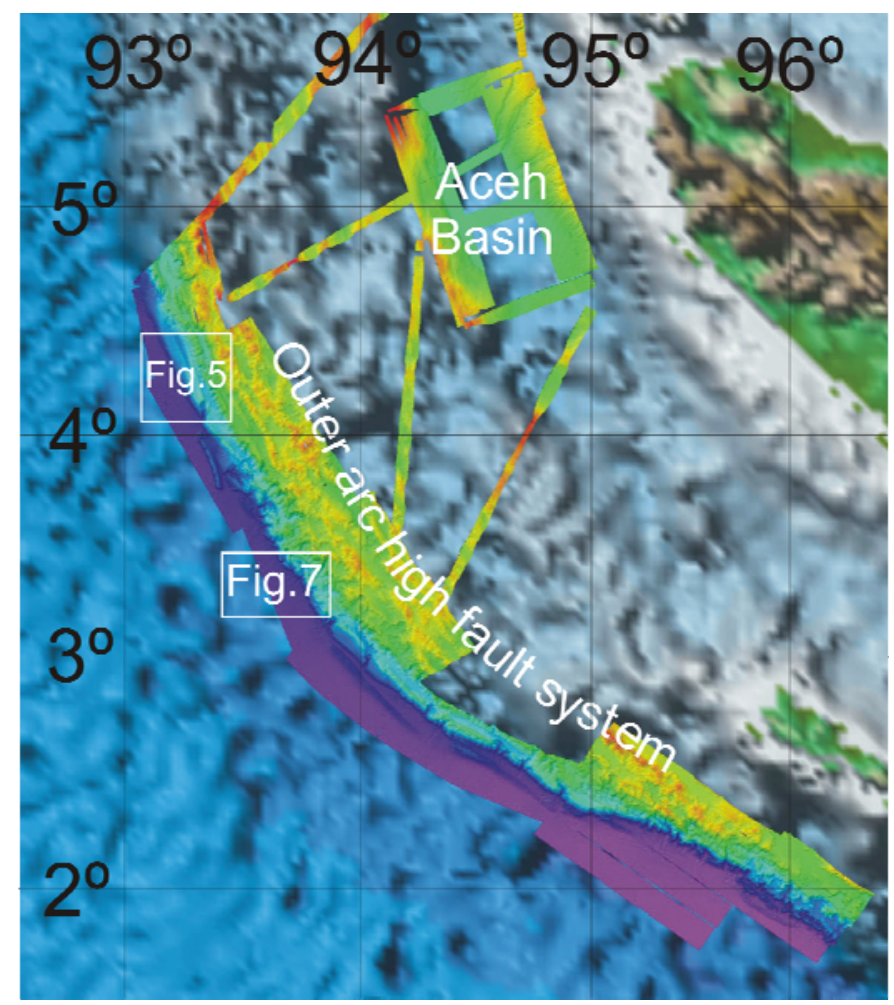

Figure 2. Overview of the HMS Scott bathymetry and the locations of Figures 5 and 7. The bathymetry is underlain by satellite altimetry (Smith and Sandwell, 1997). 


\subsection{Aceh Basin}

The Aceh Basin is a forearc basin lying $45 \mathrm{~km}$ off of northern Sumatra (Figures 2 and 3). Its western boundary is the strike-slip, West Andaman Fault (Curray, 2005). In the east lies the shelf off of Sumatra. The basin trends NNW-SSE, the basin floor is planar, slightly sloping to the SSW and with water depths of $\sim 2,500$ $\mathrm{m}$. Seabed gradients on the basin margins vary between $6^{\circ}$ and $12^{\circ}$. The new multibeam data prove that the evidence for sediment failures on the eastern margin of the basin identified on the GEBCO bathymetry are artifacts probably due to the sparse coverage of single beam data. However, the data does show incised submarine channels, indicating several phases of downcutting. There is no evidence for the channels extending onto the basin floor, nor of any significant sediment build up, such as sediment fans, at their points of entry. There are no channels on the western margin of the basin along the Andaman Fault.

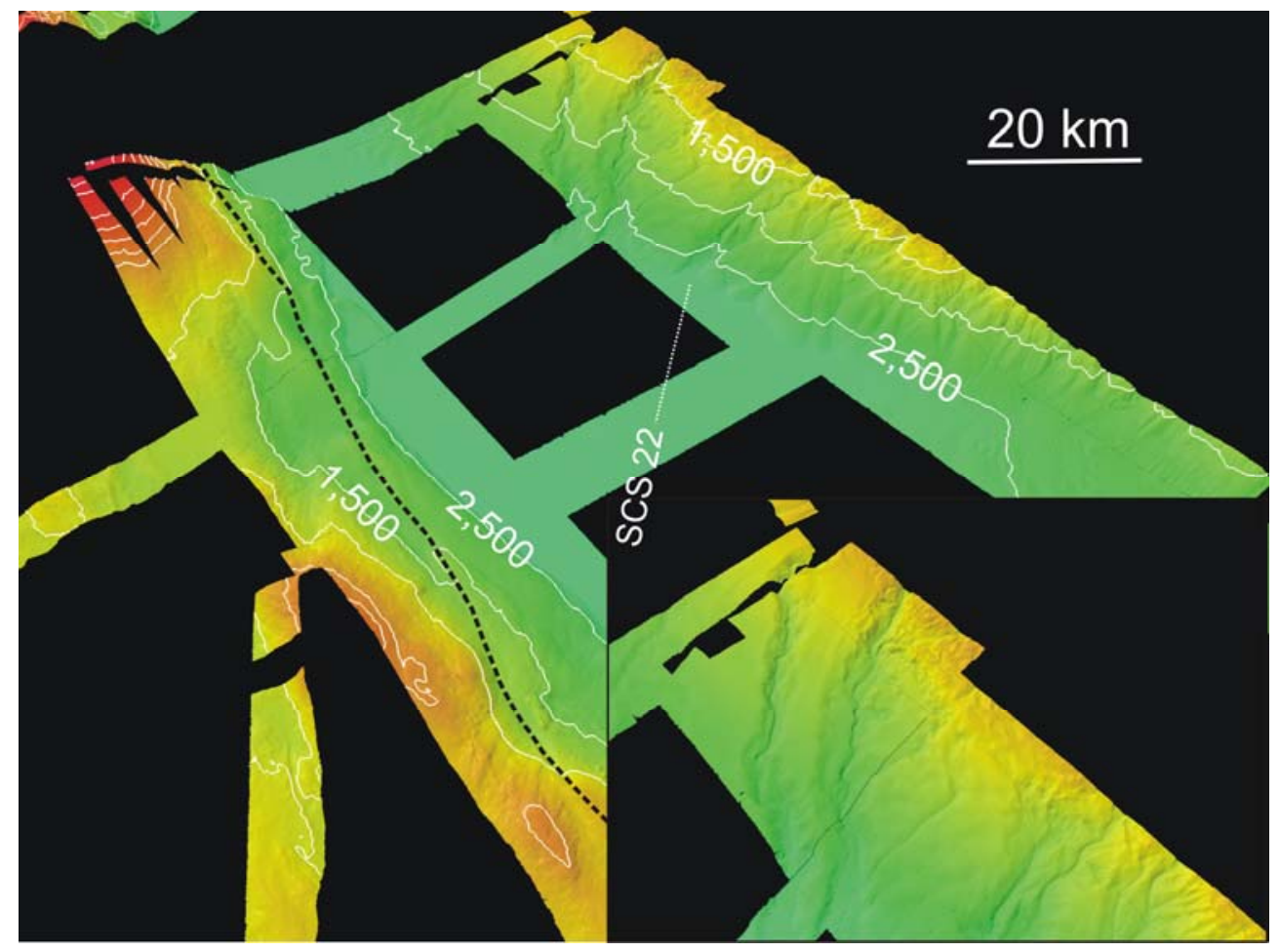

Figure 3. Morphology and bathymetry of the Aceh Basin. Bathymetric contours in metres, black dashed line - the West Andaman Fault, white dotted SCS Line 22 shown in Figure 4. Inset shows enlargement of the channels on the northwest. (Location in Figure 2.)

On the SCS data the basin infill mainly comprises parallel, moderate amplitude reflections with subordinate, semitransparent, chaotic reflections (Figure 4). The chaotic reflections form units that taper into the basin from the eastern margin. The seismic sequence is interpreted as representing dominantly hemipelagic sediment with subordinate sediment flows sourced from the eastern basin margin where they originate at the mouths of the channels identified on the multibeam bathymetry. None are recent. The flows are up to $50 \mathrm{~m}$ thick and extend up to 10 
$\mathrm{km}$ into the basin, tapering out towards the basin centre. A major unconformity surface dips westward attaining a maximum depth of $\sim 4$ secs TWT (Figure 4 ). This indicates a significant episode of subsidence along the West Andaman Fault that may relate to the downcutting observed in the channels on the eastern basin margin.

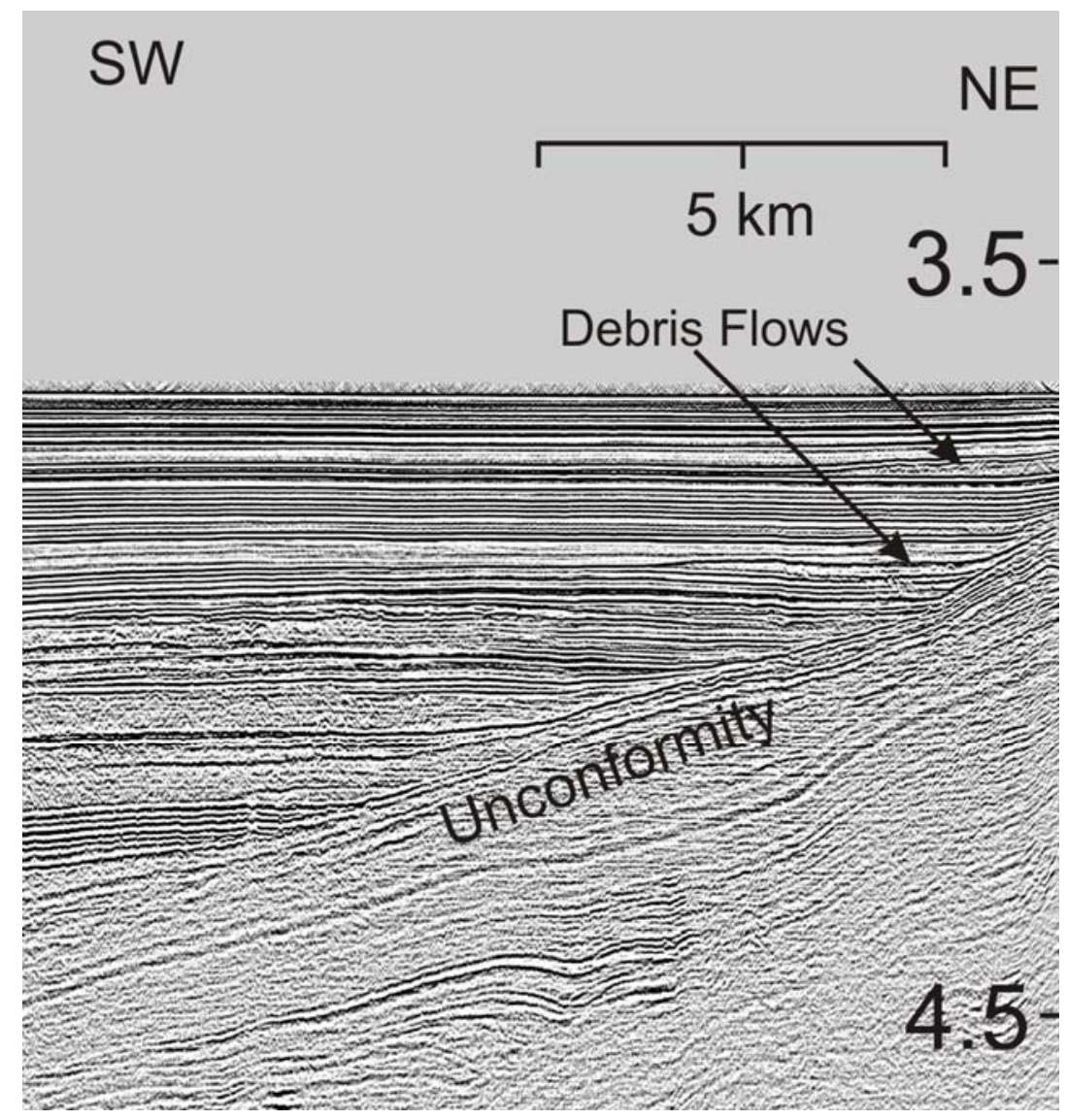

Figure 4. SCS Line 22 across the eastern Aceh Basin. Vertical scale in seconds two-way-time. See text for description. Location in Figure 3.

\subsection{Outer Accretionary Prism}

The multibeam data acquired along the plate margin cover the toe of the accretionary prism up to $75 \mathrm{~km}$ inboard (Figures 1 and 2) (Henstock et al., 2006). The lower part of the prism is defined by a rapid change in water depth from $4300-4900 \mathrm{~m}$ at the deformation front to $\sim 1500 \mathrm{~m}$ on the broad plateau at the top of the slope. The steep lower slope is $\sim 20 \mathrm{~km}$ wide, with mean slope gradients in excess of $\sim 8^{\circ}$. There are two morphologies present; those sections with thrust folds (comprising $70 \%$ of the margin mapped) and those without. Two main types of mass failure are recognized, blocky debris avalanches and sediment flows, with the majority of failures small-scale. 


\subsubsection{Blocky debris avalanches}

On the toe of the accretionary prism, located on the young thrust folds, there are planar erosional scars that on the bathymetry are usually associated with a hummocky seabed topography, with the hummocks interpreted as outrunner blocks. The failure scars are typically ellipsoidal although some exhibit linear side margins. These features represent sediment failures that are particularly common on the seaward limbs of the thrust folds. At some locations the associated slipped blocks lie outboard of the folds on the ocean basin, at others they are on the surface of upraised sections of the detached young thrust folds or lie between them and the main body of the accretionary prism. A prominent example, and probably the youngest, is found in the north of the mapped region (Figure 5). This is an $18 \mathrm{~km}$ wide, semi-elliptical slump scar on the outboard limb of a young fold. At its base, on the abyssal plain (the trench has little morphological surface manifestation at this location), the thrust fold lies at a depth of $4,400 \mathrm{~m}$ with a crest at $3,200 \mathrm{~m}$. The outboard fold limb slopes at an angle of $11-12^{\circ}$, but at the crest the slope is up to $23^{\circ}$. The failed area corresponds to the steepest gradient and greatest elevation along the fold. The top of the headwall scarp (see Hampton et al 1996 for terminology) lies on a notable, sharply defined spine, on the culmination of the fold ridge. Within the scar there are three areas of mass failure (Figure 5) with a total thickness of sediment excavation of $~ 100 \mathrm{~m}$. Measurement of the vertical steps at the boundaries between the three areas of failure indicate that the individual layer thicknesses vary between 20 and $35 \mathrm{~m}$. The outrunner blocks occupy a triangular shaped area seaward of the fold with the furthest block outboard forming the apex. The largest outrunner block is $\sim 100 \mathrm{~m}$ proud of the seabed and up to $2 \mathrm{~km}$ by $1 \mathrm{~km}$ in length/width; it lies furthest from the source, with its outboard face lying $10 \mathrm{~km}$ from the foot of the thrust fold.

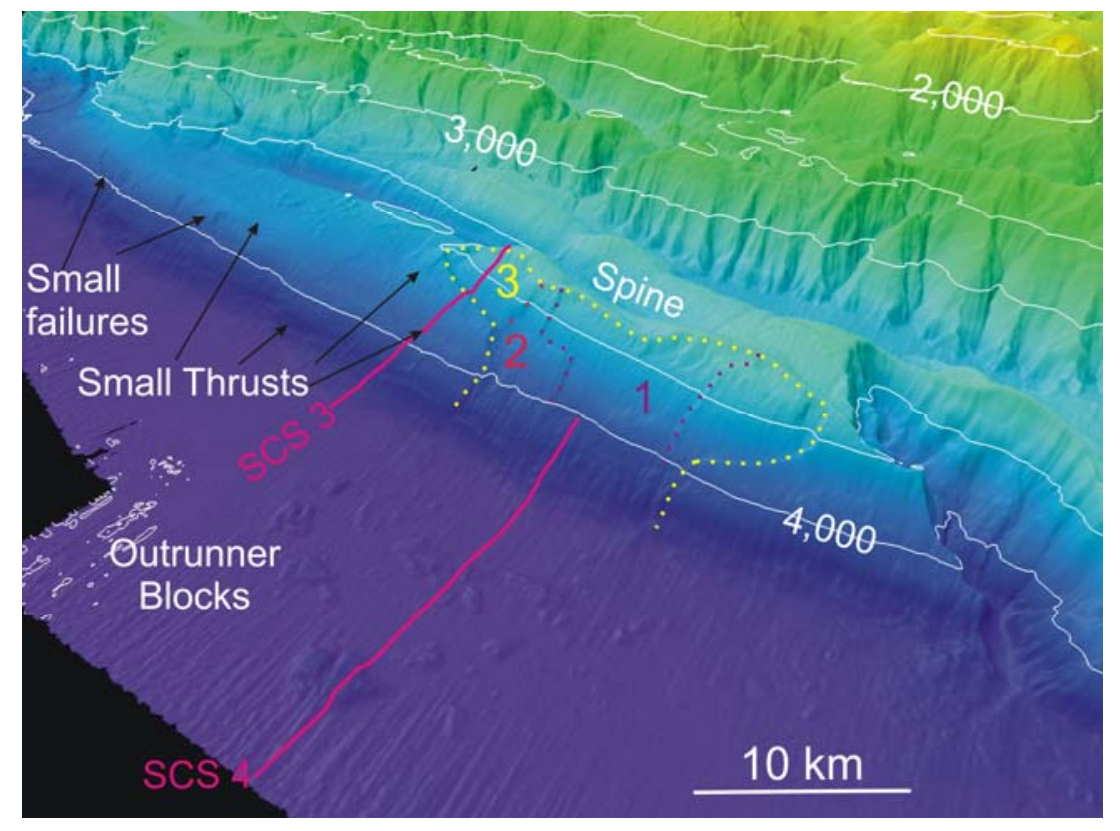

Figure 5. Morphology and bathymetry of the blocky debris avalanche in the north of the area.

Bathymetric contours in metres, internal dotted lines and numbers within the failure represent the three internal subdivisions, purple lines are the tracks of the SCS lines. Note the large 'colliform' erosion feature to the right of the debris avalanche. (For location see Figure 2). 
Two SCS lines cross the young failure, one in the centre (SCS 4) and one in the north (SCS 3) (Figure 6A and B). On northern SCS line 3 where seabed gradient is not so steep, the subseabed structure is well imaged and reveals a number of small thrusts on the outboard thrust fold limb (Figure 6a). These thrusts can be correlated with linear features on the multibeam data that may be traced along the fold limb into the failure scar (Figure 5). They generally correlate with the horizontal internal boundaries of the three failed areas. SCS Line 4 crosses the abyssal plain to seaward of the fold, revealing a complex relationship between the blocks identified on the bathymetry and the underlying substrate (Figure 6B). The blocks lying nearest to the toe of the accretionary prism appear to be part of a more continuous unit of chaotic reflections. The combination of bathymetry and seismic indicate the failure to be a blocky debris avalanche (see Normark et al., 2004). Towards the thrust fold the avalanche unit thickness tapers and its upper surface is slightly upraised, whereas the present seabed is not. Nearest the thrust fold the base of the avalanche unit is a moderate reflector but oceanward, midway between the outrunner blocks, this reflection fades and the unit thickens to a maximum of $100 \mathrm{~ms}$ (excluding the block heights), cutting down into the underlying sediment, indicating erosion during emplacment. The farthest outrunner block appears to sit on the underlying chaotic unit, which rapidly thins and tapers out beneath it. The blocky debris flow is overlain by a horizontal, seismically bedded unit (labelled 'Upper Unit' on 6B) that onlaps the margins of the outrunner blocks. It is thickest at 50 ms TWT between the thrust fold and the nearest block.

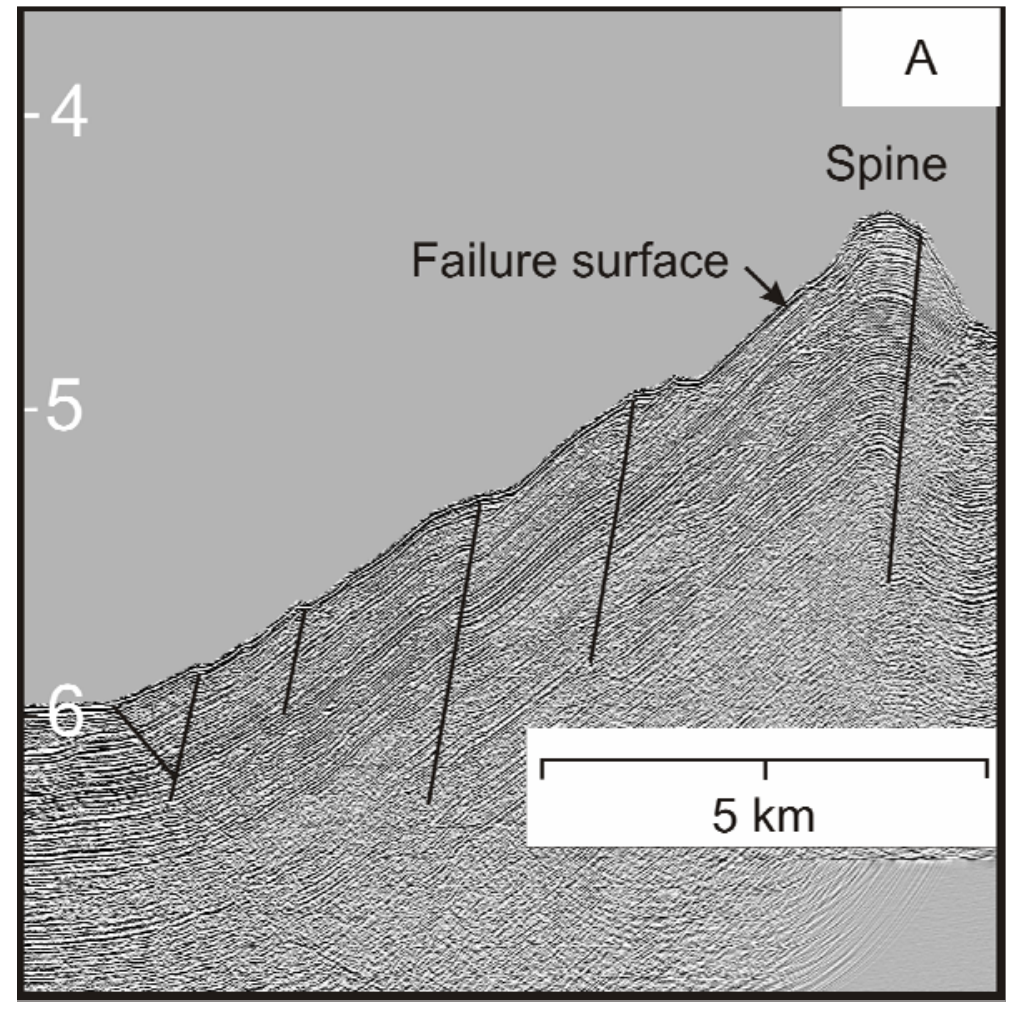

Figure 6A. SCS Line 3. The black lines are the thrusts. Vertical scale in seconds two-way-time. Location on Figure 5.

Seabed photographs reveal that the surface of the sediment forming the farthest block is not fresh (Moran and Tappin, 2006). By comparison with images of very 
recent seabed movement from farther south in the area, the formation of the block surface is apparently not recent. Photographs on the slide scar reveal fresh slumped blocks, and fissures but these are not as common as might be anticipated from a recent major failure event. In addition a plant, Umbellula $s p$. was located in the centre of the slide scar that was dated at 20 years old (Moran and Tappin, 2006).

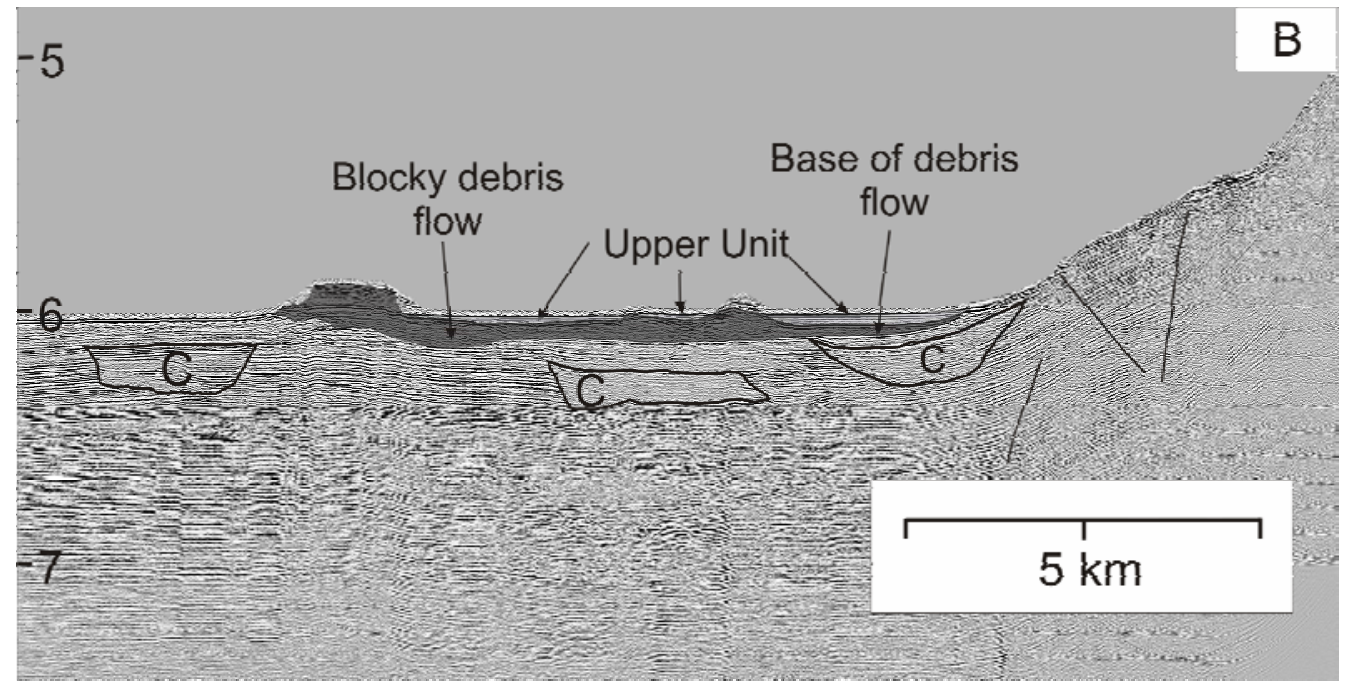

Figure 6B. SCS Line 4. See text for discussion. Vertical scale in seconds two-way-time. C labels are channels. Black lines are thrusts or faults. Location on Figure 5.

\subsubsection{Sediment Flows}

Along the toe of the accretionary prism where the young thrust folds are absent the prism toe rises abruptly from the abyssal plain and seabed gradients approach $30^{\circ}$ (Figure 7). The outboard slopes are heavily incised by numerous gullies. Landward, the gullies cut through the older thrust folds and lead into arcuate, incised 'colliform' features (described because of their similarity to a cauliflower) that are similar in form to stream catchments in mountainous regions. Seaward, the gullies lead into channels on the abyssal plain, which are up to $100 \mathrm{~m}$ deep. The channel morphology varies; with some channels are linear, others are meandering. In some locations at the mouth of the gullies there are small (10 - 20 $\mathrm{m}$ high) sediment blocks. Meandering channels are commonly seen to have a number of episodes of activity. On the abyssal plain there are sediment waves, and at one location a sediment fan has been formed.

\section{Discussion}

Mapping of the convergent margin offshore of Sumatra using swath bathymetry, SCS and seabed photography reveals that seabed mass wasting takes place mainly through small-scale events. Within the Aceh forearc basin there is no evidence for large-scale landslides or slumps that may have contributed to local runups during tsunamis. There is no evidence to indicate that any sediment flow is very recent. 
Sediment is transported into the basin through channels, by small-scale sediment flows. Deposition in the basin is mainly hemipelagic.

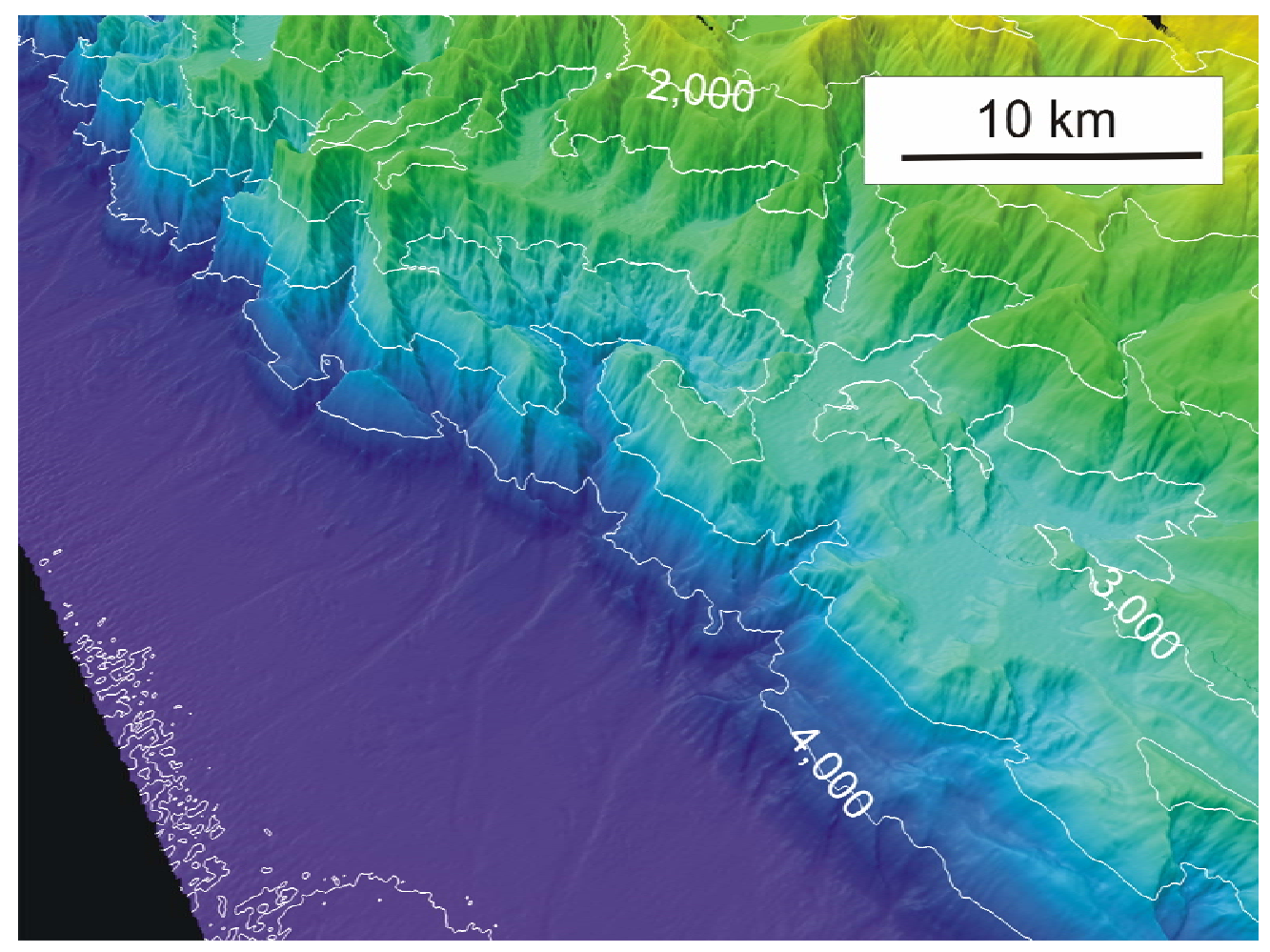

Figure 7. Toe of accretionary prism without thrust folds. Bathymetric contours in metres,

On the outer part of the accretionary prism there are two main types of mass wasting process, blocky debris avalanches and sediment flows. On the seaward faces of young thrust folds the avalanches are interpreted to be formed in cohesive, but relatively unconsolidated, sediment. The mechanism of failure is interpreted to be due to a combination of factors, primarily tectonic oversteepening of thrust fold limbs, with the failures controlled by movement along small-scale thrusts activated during earthquakes. These thrusts we interpret to reflect larger, deeper seated seaward dipping thrusts (landward vergence) (Henstock et al 2006). There is no evidence of fluid expulsion. The thickness of the failed blocks is controlled by the bedding, inherited from the original depositional sediment character. Failures take place on the steepest slopes. Internal structures seen on the failure scars may not represent individual failures that are widely separated in time. In the instance of the blocky debris avalanche described in detail, although there are three internal boundaries, these represent one episode of failure. Where young thrust folds are absent, the deeply dissected, steeply sloping, gullied morphology is interpreted as a result of incremental sediment failure, mainly through headwall erosion. As recounted by Hampton (1972) we interpret initial failure of larger blocks of sediment in the source regions that break down during transport. The resulting finer-grained sediment is transported onto and deposited on the abyssal plain forming sediment waves and sediment sheets. Of the debris avalanches and sediment flows, none can confidently be identified as of very recent origin (for example formed on the $26^{\text {th }}$ of December 2004). This throws into perspective a widely held view that earthquakes trigger submarine failures that may create destructive tsunamis. 
The overall regional framework of sediment supply to the convergent margin off of Sumatra may provide some answers as to the lack of major landsliding. Sediment forming accretionary prisms may be derived from the land or the subducting plate, and the morphology of the prism off of Sumatra indicates that it is sediment starved. There is no evidence for significant sediment input from the landward direction. No major canyons cross the accretionary prism. Sediment derived from the land is of small volume and trapped within the Aceh forearc basin. The interior of the prism is degraded; there appears to be little erosion taking place on the fold limbs, the synclines between the uplifted thrust folds form elongate basins that are flat floored with little evidence of sediment fans, they are filled mainly with hemipelagic sediment (Figure 2). On the prism toe, the sediment derived by mass wasting is small scale. The sediment comprising the accretionary prism appears to be dominantly derived from the oceanic plate. On the prism toe, there is a southward decrease in the size of the thrust folds, and an increasing isolation from the prism toe, and an increase in their erosion. All these features indicate a decrease in sediment supply in a southward direction.

On the abyssal plain, the seismic data record a change in the sedimentation regime at some previous time (Figure 6B). An extensive system of channels, is present only at depth; there are none at the surface. Channel size and internal structure records a previous period of vigorous activity that is margin parallel. Consideration of sedimentation in the Indian Ocean suggests that there should be a considerable volume of sediment delivered to accretionary prism off Sumatra that is derived from the Bengal Fan (Curray, 2006). However, this does not seem to be the case. To the contrary, our data indicate a southward reduction in the sediment section entering the subduction system, that indicates a reduction in the volume of sediment delivered to the prism. We attribute this to the collision, during the early Quaternary, of the Ninetyeast ridge with the Sunda margin (Figure 1). This collision resulted in a cut off of supply as sediment was diverted away from the margin.

\section{Conclusions}

Although earthquakes trigger submarine landslides that may create destructive tsunamis, there are other factors, apart from earthquake magnitude and frequency, that require consideration when assessing the tsunami hazard from landslides along convergent margins. These include sediment supply and tectonism. The Sumatra margin is prone to large earthquakes, but is sediment starved. This is due to the small volume of sediment entering the margin, both from land and the ocean. Landward derived sediment is mainly trapped in the Aceh forearc basin. Although a potential location for large landslides, the restricted sediment input to the Aceh Basin, leads to small-scale sediment flows, widely spaced in time.

On the prism toe, there is a close relationship between sediment failure and local small-scale tectonics. The common blocky debris avalanches are mainly confined to the young thrust folds, with failure taking place on the steep outboard fold limbs in soft cohesive sediment, the thicknesses of the slumped blocks being controlled by bedding planes. Failure is in part determined by movement along small scale seaward dipping thrust planes. Although small in themselves the 
thrusts reflect underlying, large scale landward thrust vergence. Where young thrust folds are absent the presence of dominant sediment flows may reflect a different style of thrust vergence and/or more lithified sediment. The most likely trigger for the both styles of failures is considered to be earthquakes.

The volume of sediment derived from the oceanic plate is limited despite the proximity of the massively thick Bengal Fan. The explanation for this apparent contradiction is explained by collision in the early Quaternary along the subduction zone with the Ninetyeast Ridge, that resulted in the diversion of sediment away from the Sumatra region. This reduction in sediment input is regarded as contributory to the small scale nature of sediment failure observed along the Sumatra margin. In both the Aceh Basin and on the prism toe, the scale of sediment failure is considered a limited threat as a causative mechanism for a major locally generated tsunami.

\section{Acknowledgements}

We thank the ship's company of the HMS Scott a UK Royal Navy survey vessel, for acquiring the multibeam data during marine scientific research coordinated by the Joint Environment Directorate of Defence Intelligence. We also thank; The Royal Navy, British Geological Survey, National Oceanography Centre, United Kingdom Hydrographic Office, and the Government of Indonesia. The Government of Canada is thanked for funding the use of the seismic equipment provided by the Canadian Geological Survey. General thanks to the British Embassy Jakarta, British Broadcasting Corporation, Discovery Channel, Science Applications International Corporation, BP Marine Limited, Oceaneering International Corporation, and Darlow Smithson Productions. Many thanks to Homa Lee and Gary McMurtry for providing reviews at short notice that considerably improved the manuscript. David Tappin publishes by permission of the Executive Director of the British Geological Survey (NERC).

\section{References}

Curray JG. (2005) Tectonics and history of the Andaman Sea region. Journal of Asian Earth Sciences. 25: 187-232.

Goldfinger C Kulme LD McNeill LC Watts P (2000) Super-scale failure of the southern Oregon Cascadia margin. Pure and Applied Geophysics. 157: 1189-1226.

Hampton M (1972) The role of subaqueous debris flow in generating turbidity currents. Journal of Sedimentary Petrology. 42: 775-993.

Henstock T McNeill LC Tappin DR. (2006) Seafloor morphology of the 26 December 2004 Indian Ocean earthquake rupture zone. Geology. 34: 485-488. doi: 10.1130/22426.1. 
Lee HJ Locat J Desgagnes P Parsons J McAdoo B Orange D Puig P Wong F Dartnell P Boulanger E (2007) Submarine Mass Movements. In C.A. Nittrouer (ed) Continental-Margin Sedimentation: Transport to Sequence. Blackwell/IAS.

McAdoo BG Capone MC Minder J (2004) Seafloor geomorphology of convergent margins: implications for Cascadia seismic hazard. Tectonics. 23: TC6008, doi:10.1029/2003TC001570 Moran K Tappin D (2006) SEATOS 2005 Cruise Report: Sumatra Earthquake and Tsunami Off shore Survey (SEATOS). pp92 [Online] available at http://ocean. oce.uri.edu/seatos.

Newcomb KR McCann WR (1987) Seismic history and seismotectonics of the Sunda arc. Journal of Geophysical Research. 92: 421-439.

Ortiz M Bilham R (2003) Source area and rupture parameters of the 31 December $1881 \mathrm{Mw} \sim 7.9$ Car Nicobar earthquake estimated from tsunamis recorded in the Bay of Bengal. Journal of Geophysical Research. 108: doi:10.1029/2002JB001941.

Smith, WHF Sandwell DT (1997) Global seafloor topography from satellite altimetry and ship depth soundings. Science. 277: 1957-1962.

Tappin DR Watts P McMurtry GM Lafoy Y Matsumoto T (2001) The Sissano, Papua New Guinea tsunami of July 1998-offshore evidence on the source. Marine Geology. 175: 1-23. 